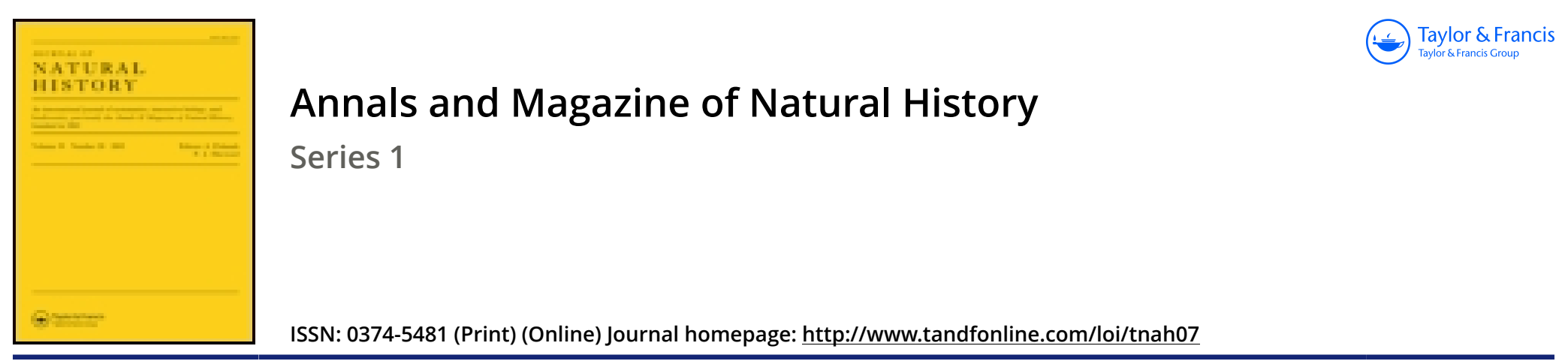

\title{
On the embryology of Actæon
}

\section{Vogt}

To cite this article: M. Vogt (1846) On the embryology of Actæon, Annals and Magazine of Natural History, 17:110, 137-139, DOI: 10.1080/037454809495574

To link to this article: http://dx.doi.org/10.1080/037454809495574

册Published online: 17 Dec 2009.

Submit your article to this journal 중

Q View related articles $₫$ 
of a nearly regular, convex, conical form and nearly central tip. The animal of this shell has dissolved a space on the surface of the other Dispotea of the size of the edge of the aperture of its shell.

No. 5. is a Cardita with a Dispotea on each of its valves placed as in specimen No. 4 , that is, with one of the edges of the shell close on the lower edge of the bivalve; and there is a single valve of the same species of Cardita with another Dispotea in a similar situation.

It is to be observed, thet under each of these shells, instead of the animal having eaten, or rather dissolved away part of the surface of the bivalve so as to form a sinoother surface, each of the animals has deposited on their supporter a circumscribed layer of rather transparent hard calcareous matter of the exact size and form of the mouth of the shell, which fills up the greater part of the space between the ribs and forms an even and smooth base, and in one case it covers over some Serpula and other bodies which were attached to the bivalve. I cannot find any indication of a muscular scar on this deposit. These Dispotece have a thick pale brown shell, darker towards the upper part of the cavity; the outer surface is covered with thick, irregular, radiating, flattish-topped ribs, crossed by irregular concentric ridges, having oblong or linear intervening nets, and the surface of one of the specimens is marked with some itregtular cross-ridges eaused by the inequalities of the shell. In one of the Dispotec the internal appendage or back of the shell is near the lower edge of the bivalve, and the other has it near the umbo.

I believe that the whole of these specimens, belong to a single species (No. 1 to 4 is D. tubifera, Say, and No. 5 is D. rugasa, Lesson), but it is curious to observe, that when within the cavity of another shell, it is white, low, and the animal did not dissolve any part of the surface to which it was attached; that when on the outer surface of the shell, it is high, thick, dark brown, and in some cases it alssorbs the surface to which it is attached; and at otbers that it deposits a layer on the surface of the shell to which it is affixed, of the size of the margin of the shell itself. I may observe that generic characters have been formed on less variations in habit and less characters.

In the same collection are two specimens of Pecten with two Crepidula on each : they have modified the form of the surface of each shell, and the animals have absorbed a very thin layer from the surface of each part of the shell to which they are attached.-J. E. Gray.

\section{On the Embryology of Actæon. By M, VogT*.}

The embryology of the Actconn has been the principal object of my researches; I have seen the coupling of this interesting little mollusk, I have been present at the laying of the eggs, which takes place during some hours after the coicus, and $I$ have thus had an opportunity of following, from hour to hour, up to the present day, the changes which the egg undergoes during a month. I have thas been able to ascertain that the separation of the vitellus is complete in this species, and that the division into eight parts offers a very

* Extract of a letter addressed to M. Milne Edwards. Ann. \& Mag. N. Hist. Vol. xvii. 
singular peculiarity, inasmuch as the four primitive parts of the vitellus do not each separate into two spheres, as is the case in other known animals, but that, on the contrary, the four new spheres, which are much smaller, are deposited upon the old ones.

The embryo presents, from its first appearance, a kind of thick disc, intersected by a median slit which might be taken as analogous to the primitive line of vertebrated animals, if subsequent observations did not show that it is at the spot which this slit occupies that the mouth is formed. The embryo is composed, some hours after the appearance of this slit, of two lateral wheels furnished with large vibratile cilia, of a beak-like prominence, which afterwards becomes the foot, and of a posterior rounded part in which the intestines are formed.

Of all the internal organs, the ear is first developed; in a subject now under observation the ears are very visible, whilst the eyes are not yet formed.

After the organs of hearing, the shell is formed; I have been able to trace all the phases of its development, as well as of the operculum which clothes the posterior surface of the foot. I now observe that the tail is on the point of detaching itself from the animal ; all the loops which retained it have disappeared, and the membrane, which clothed it internally, envelopes the viscera tightly, leaving a large space between them and the shell.

The digestive apparatus, which is formed after the shell, is composed of a semicircular mouth, situated between the wheels at the base of the foot, of an elongated cesophagus, which terminates in a large stomachal pouch, and of an intestine curved in the form of a hook, which terminates in an anus situated on the right. The liver is entirely separated from the intestine on its "first appearance; it communicates afterwards with the stomachal pouch by a large aperture.

The stomachal pouch, in which I have often seen infusoria, especially Navicula, appears to be transformed into a buccal mass. I have seen, in the embryos of another species of Nudibranchiæ, and which greatly resemble the embryos of Acteon, that a protuberance furnished with projections in the form of spines was developed in the inside of this pouch. Probably this organ was the first vestige of the tongue.

Now, nearly thirty days after the laying of the eggs, my embryos swim freely in water by means of their large lateral wheels. It is remarkable that these agile animals, which for nearly a fortnight are nourished on infusoria, have yet no trace of circulation. The heart does not yet exist, and it is impossible that I should have overlooked it. This fact interests me greatly; and as I have seen the heart in embryos of other mollusks which were much more advanced in their development, there could be no possible error on this point.

I hope to be able to continue the researches of which I have given a very incomplete sketch, by bringing some living embryos, or rather larvæe of Actcon, to Paris. I intend to follow their development during the wnter, in order to ascertain the changes which must still 
occur, for the present form of these embryos and their anatomy is quite as much separated from that of the adult Acteon as is that of a caterpillar and a butterfly.

I will add another observation which may perhaps interest you. A Balanus, which I had detached with several others and preserved alive in a bottle, deposited in my presence a prodigious quantity of little ones, which came out with the stream of water which the animal emitted at the moment of each expiration. The young barnacles had only one frontal eye and three pairs of natatory feet, the two last pairs of which were divided each into two branches. They resembled entirely Crustacea of the genus Cyclops.-Comptes Rendus, Oct. 6, 1845.

HASSALI'S BEITISH 'FRESHWATER ALGAE.'

To the Editors of the Annals of Natural History.

Gentlemen,-In the accompanying letter I have carefully abstained from any allusions which might be regarded as offensire by your reviewer, and have confined myself as closely as possible to a refutation of certain passages of the review, which, if allowed to pass without notice, would prove injurious to my book, and which are for the most part inaccurate in themselves; I therefore trust that your sense of fairness will allow you to give my communication insertion in the February Number of the 'Annals.' I should wish the letter to be published in full; and as no opportunity was afforded to me to notice the review in the same Number of the 'Annals' in which that review appeared, none ought to be conceded to the reviewer in the same Number in which my letter appears*.

I remain, Gentlemen, your obedient servant,

January $3,1846$.

Artuur Hill Hassalx.

"Reddere cuique sua est æqui bonique hominis."

Without wishing to charge your reviewer, in his notice of the History of the British Freshwater Algæ,' with undue partiality or prejudice, I believe that I shall be able to show, that, on certain points, he has indulged in animadversion to an extent, which on a careful and candid examination of the work in question is not justified.

It is urged therein against the originality of my work, that not a few of the plates which illustrate it are taken from the works of other writers on the Algæ; and further, that, although copies, no acknowledgement of the fact is made.

In answer to these statements, I beg to observe, that five only out of the 103 plates forming the volume of illustrations are reprints of plates previously published, and that each of these bears the name of its original designer, Thuret, Kützing and Varley.

The figures of many of the Desmidice are undoubtedly taken from

* We are very willing to comply with the above singular request of $\mathrm{Mr}$. Hassall, and in the mean time leave our readers to form their own judgement.-Ev. 